\title{
Behavior of self- compacting concrete incorporating calcined pyrophyllite as supplementary cementitious material
}

\author{
Mansour Sabria Malika
}

Research Unit: Materials, Process and Environment, Civil Engineering department, University M’Hamed Bougara of Boumerdes, Algeria

Corresponding Author: s.mansour@univ-boumerdes.dz

Received: 03-07-2020

Accepted: 24-08-2020

\begin{abstract}
The current trend of industrial concrete leans more towards the use of selfcompacting concrete. These must have fresh properties well defined as fluidity, filling ability and resistance to segregation. However, to ensure the rheological stability, use mineral fines is required. In this work, powder of calcined pyrophyllite (CP) was used as cement substitution at level of $10 \%$ and $20 \%$ by weight. The interest is focused on the role played by the calcined pyrophyllite to produce SCC with reduced impact environmental.. Calcination of pyrophyllite powder was carried out at $750{ }^{\circ} \mathrm{C}$. Its effect on the workability and mechanical properties of self-compacting concrete is analyzed. The results show that the properties of workability of SCC containing 10\% of calcined pyrophyllite tested at fresh state (Slump Flow, $\mathrm{T}_{50}$, passing ability and segregation resistance) are almost identical to those of the control SCC. Furthermore, the calcined pyrophyllite increases the compressive strength, tensile and flexural strength of SCC approaching without exceeding those of the control SCC. It seems that $10 \%$ of calcined pyrophyllite is the optimum replacement rate which improves mechanical strength compared to $20 \%$. Replacing cement with the calcined pyrophyllite aims to save cement and reduce the $\mathrm{CO}_{2}$ emissions released during the manufacture of cement.
\end{abstract}

Key words: Calcined Pyrophyllite; Self-compacting concrete; Mechanical strength; workability.

\section{Introduction}

Self-compacting concrete SCC is a very fluid, stable and homogeneous concrete. It differs from ordinary concrete by its fresh properties and moldability. The SCC is formulated to obtain the optimal compromise between fluidity and resistance to segregation and to bleeding (ACI, 2003). However, to ensure the fresh stability of SCC, the use of mineral additives (fine) is required. But researches are still relevant to the understanding of the fresh and physical- mechanical behavior of SCC. The addition of finely divided siliceous materials to concrete mixes in order to improve the workability of fresh concrete and subsequently the durability of its hardened state is an established practice in modern concrete technology (Uysal \& Sumer, 2011; Busari et al., 2019). Siliceous materials of low reactivity are utilized solely to improve the workability of fresh concrete deficient in fines (Ouldkhaoua et al., 2020). Generally, cementitious or pozzolanic materials are preferred because they eventually also contribute to the strength and durability of the hardened concrete (Belaidi et al., 2015; Belaidi et al., 2012; Boukhelkhal et al., 2016; Boukhelkhal et al., 2012; Aghabaglou et al., 2014; Dembovska et al., 2017; Ouldkhaoua et al., 2020).

A wide variety of natural materials as well as industrial by-products contain silica that has pozzolanic activity. To maximize its pozzolanic activity, natural pozzolans usually require grinding to cement fineness and may need to be calcined prior to its application (Krajèi et al., 2013; Mansour et al., 2012; Mansour et al., 2013). Indeed, the thermal treatment collapses the crystalline structure of the mineral by evaporating the lattice hydroxyl groups, creating a highly reactive amorphous alumina-silicate that has high affinity for reaction with cement hydration 
products (Tregger et al., 2010). It has been demonstrated by many researchers (Bijeljié et al., 2014; Madandoust \& Mousavi, 2012) that kaolinit in form of metakaolin (calcined kaolinit) can be used as an excellent cement substitute. However, if other clay minerals' pozzolanic reactivity was improved, the use of calcined clays would present a good choice in addressing the cement production reduction problem (Rashad, 2015). Recently, natural pyrophyllite was discovered in Algeria. Being calcined and finely ground, becomes a pozzolanic material reacts with calcium hydroxide $\mathrm{Ca}(\mathrm{OH})_{2}$ released during the hydration of cement to form the calcium silicate hydrates $\mathrm{CSH}$ and allow to improve the fresh and mechanical properties of concrete. The pyrophyllite $\left(\mathrm{AI}_{2} \mathrm{O}_{3} .4 \mathrm{SiO}_{2} \cdot \mathrm{H}_{2} \mathrm{O}\right)$ is a relatively rare mineral because it is not found everywhere in the word; few studies have been done on pyrophyllite used as a cementitious material. Therefore, it has generally been neglected in commercial circles, but its high content of silica and alumina and its physical and chemical properties make it useful in many industries, primarily in refractories, ceramics and various uses.

Pyrophyllite is a soft, white or pale colored silicate mineral. Hydrated aluminum silicate $\mathrm{Al}_{2} \mathrm{Si}_{4} \mathrm{O}_{10}(\mathrm{OH})_{2}$, comprised as the main constituent of some schistose rocks. Pyrophyllite deposits are usually associated with metamorphic rocks, in which the mineral forms packets of pyrophyllite slate or compact agalmatolite aggregates. It sometimes occurs in hydrothermal quartz and ore veins. Pyrophyllite is both fire- and acid-resistant. It is used commercially as a highly aluminiferous raw material for refractory products and as a chemically stable and insulating material. It has Mohs hardness of 1-2 and specific -gravity of 2.6-2.9. Pyrophyllite (from the Greek words for fire and leaf) gets its name from the fact that it exfoliates when water is driven off upon heating, leaving a flaky mass. In pyrophyllite, two silicate layers are sandwiched with a gibbsite layer between them. Thus the overall structure of natural pyrophyllite can be imagined as stacked silicate-gibbsite-silicate sandwiches. After calcination pyrophyllite powder lost its sticky property when combined with water and its color changed from light grey to light orange.

In the literature, the raw pyrophyllite is used as an additive or substitute materials at different amounts into a conventional porcelain mixture (Mukhopadhyay et al, 2009). Extensive and relevant studies on the use of pyrophyllite in building materials such as mortar or concrete are even scarcer (Anggraini et al, 2014). Demez \& Karakoç, (2020) assessed the residual mechanical properties of high strength concretes made with pyrophyllite aggregate after high temperature. Terzic' et al, (2020) studied the utilization possibility of activated pyrophyllite in building materials as a pozzolanic mineral additive. Researches of Lauw and Besari (2001) reported that the calcined pyrophyllite decreased strength of lightweight concrete. They showed that it can be effectively used as a partial replacement of cement but to improve its pozzolanic activity, calcination temperature and finesse must be increased.

The available studies on the application of pyrophyllite are predominantly limited to its utilization in ceramic materials (whitewater, tiles, porcelain) as a replacement of quartz, clay or feldspar (Amritphale et al., 2006; Mukhopadhyay et al., 2010).

Therefore, the general idea behind our investigation was to use Algerian calcined pyrophyllite powder as cement substitution at a rate of $10 \%$ and $20 \%$ to assess its potential in selfcompacting concrete providing additional benefits. This, for economic and environmental reasons by reducing the cost of manufactured cement and $\mathrm{CO}_{2}$ gas released. Its effect on the workability and mechanical properties of self-compacting concrete was studied.

\section{Materials and Experiment}

\subsection{Materials}

Cement CEM II / A 42.5 was used. Natural ground sand with a maximum size of $3 \mathrm{~mm}$ was used as natural fine aggregate with a specific gravity of $2.69 \mathrm{~g} / \mathrm{cm}^{3}$, fineness modulus of 2.31 and its 
water absorption value is $4.5 \%$. Coarse aggregates $3 / 8$ and $8 / 15$ with specific gravity of 2.66 $\left(\mathrm{g} / \mathrm{cm}^{3}\right)$ were also used. Superplasticizer MEDAFLOW RE 25, a high range water reducer polycarboxylate was used to achieve the required workability of the SCC mixes. Superplasticizer having a pH of 7 , a density of 1.06 and chlorine content $<1 \mathrm{~g} / \mathrm{l}$ and a $25 \%$ solids content. Used pyrophyllitte comes from the region of Bechar located $1150 \mathrm{~km}$ south-west of the capital Algiers in the form of rock pieces. It was crushed and pulverized using a mill, sieved through a sieve of 80 microns and then calcined at $750^{\circ} \mathrm{C}$ for $3 \mathrm{~h}$.

Physical properties and chemical compositions of the calcined pyrophyllite CP and cement are given in Table 1 and Table 2. Furthermore, XRD analysis of pyrophyllite and calcined pyrophyllite are shown in Figure 1 and Figure 2.

Table 1. Physical properties of Calcined pyrophyllite CP and Cement

\begin{tabular}{|l|l|l|}
\hline Caracteristics & CPC & Cement \\
\hline \hline Specific surface area $\left(\mathrm{cm}^{2} / \mathrm{g}\right)$ & 6200 & 4400 \\
\hline Specific gravity $\left(\mathrm{g} / \mathrm{cm}^{3}\right)$ & 2.55 & 2.99 \\
\hline Mineral activity $(\mathrm{mg}) \mathrm{Ca}(\mathrm{OH})_{2} / \mathrm{g}$ & 118.3 & - \\
\hline
\end{tabular}

Table 2. Chemical composition of CP and Cement (\%, by weight)

\begin{tabular}{|l|l|l|l|l|l|l|l|l|l|l|l|}
\hline Oxydes & $\mathrm{SiO}_{2}$ & $\mathrm{Al}_{2} \mathrm{O}_{3}$ & $\mathrm{Fe}_{2} \mathrm{O}_{3}$ & $\mathrm{CaO}$ & $\mathrm{MgO}$ & $\mathrm{SO}_{3}$ & $\mathrm{~K}_{2} \mathrm{O}$ & $\mathrm{Na}_{2} \mathrm{O}$ & $\mathrm{P}_{2} \mathrm{O}_{4}$ & $\mathrm{TiO}_{2}$ & $\mathrm{PF}$ \\
\hline \hline CPC & 53.77 & 27.33 & 8.03 & 1.23 & 0.70 & 1.24 & 2.86 & 0.64 & 0.15 & 1.10 & 2.94 \\
\hline Cement & 20.71 & 5.45 & 3.63 & 60.4 & 2.15 & 2.37 & 0.65 & 0.23 & - & - & 4.28 \\
\hline
\end{tabular}

Chemical analysis of the calcined pyrophyllite CP shows that it contains a significant rate of silica and alumina. Hence it is categorized as alumino-silicate material. The oxide composition of calcined pyrophyllite used in this investigation was about $53.77 \%$ silica, $27.35 \%$ alumina and $2.94 \%$ was loss on ignition. In addition, calcined pyrophyllite contains impurities as $\mathrm{MgO}, \mathrm{SO}_{3}$, $\mathrm{K}_{2} \mathrm{O}, \mathrm{Na}_{2} \mathrm{O}, \mathrm{P}_{2} \mathrm{O}_{4}$ and $\mathrm{TiO}_{2}$. Moreover, figure 1 show that the crystalline phases of the pyrophyllite are quartz, kaolinit and gypsum, ilite, pyrophyllite and hematite. But after calcination at $750{ }^{\circ} \mathrm{C}$ for 3 hours, kaolinit and gypsum disappeared and new minerals were formed as the anhydride.

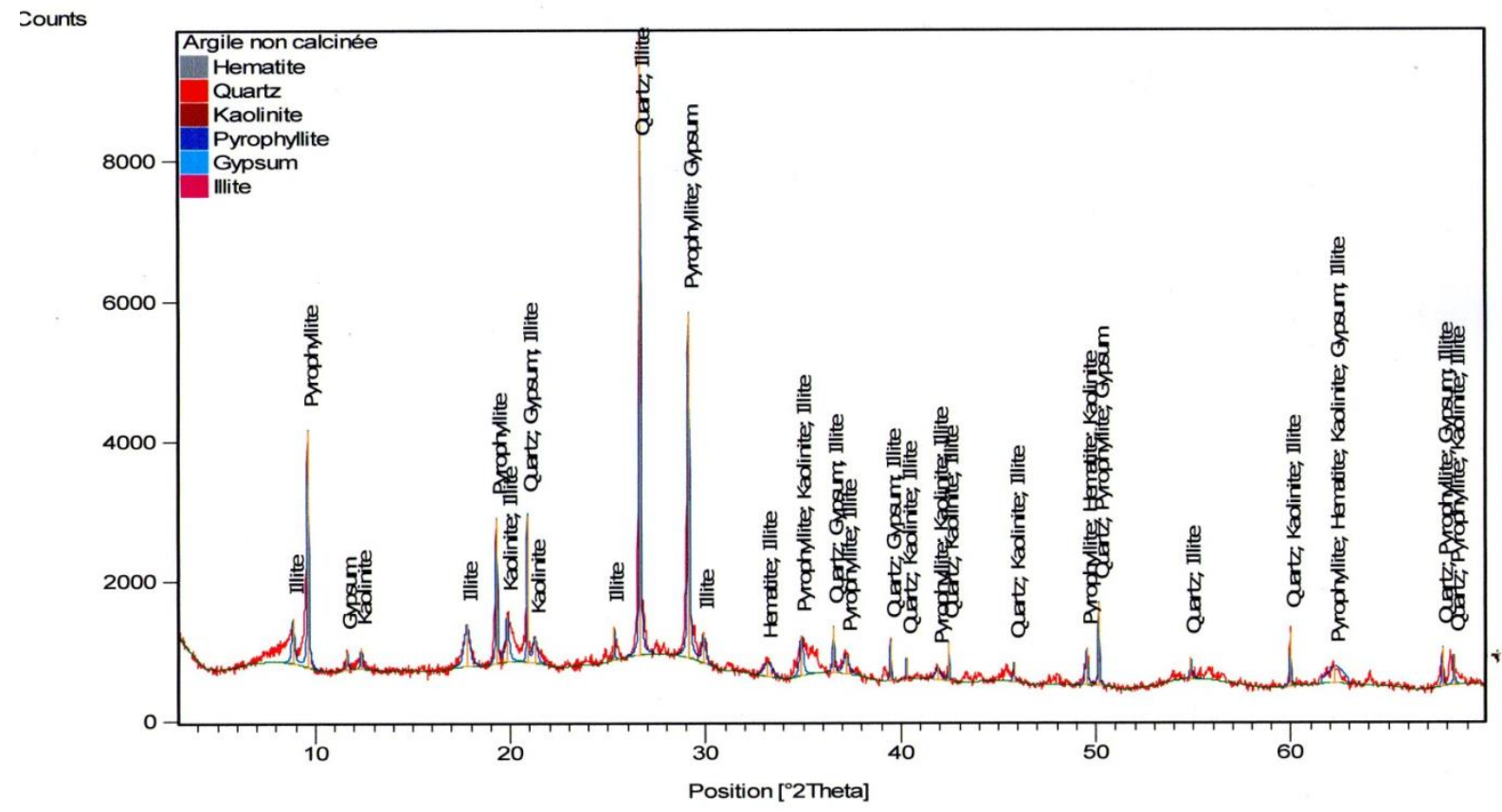

Fig 1. X-ray diffraction of the pyrophyllite ( $\mathrm{Cu}$ ka filter $\mathrm{Ni}$ ). 
According to figure 2, XRD analysis confirms that applied thermal cycle was not enough to decompose the illite and quartz. Temperature of $750^{\circ} \mathrm{C}$ was chosen based on the works of Samet et al., (2007), Rabehi et al., (2014) and Rashad, (2015). At this temperature, there is a departure of the water content (the dehydroxylation) and the formation of material with an amorphous structure which makes it more reactive than the starting clay. The heat treatment causes the transition of the crystalline phase ordered to a disordered phase by a collapse of the crystal lattice.

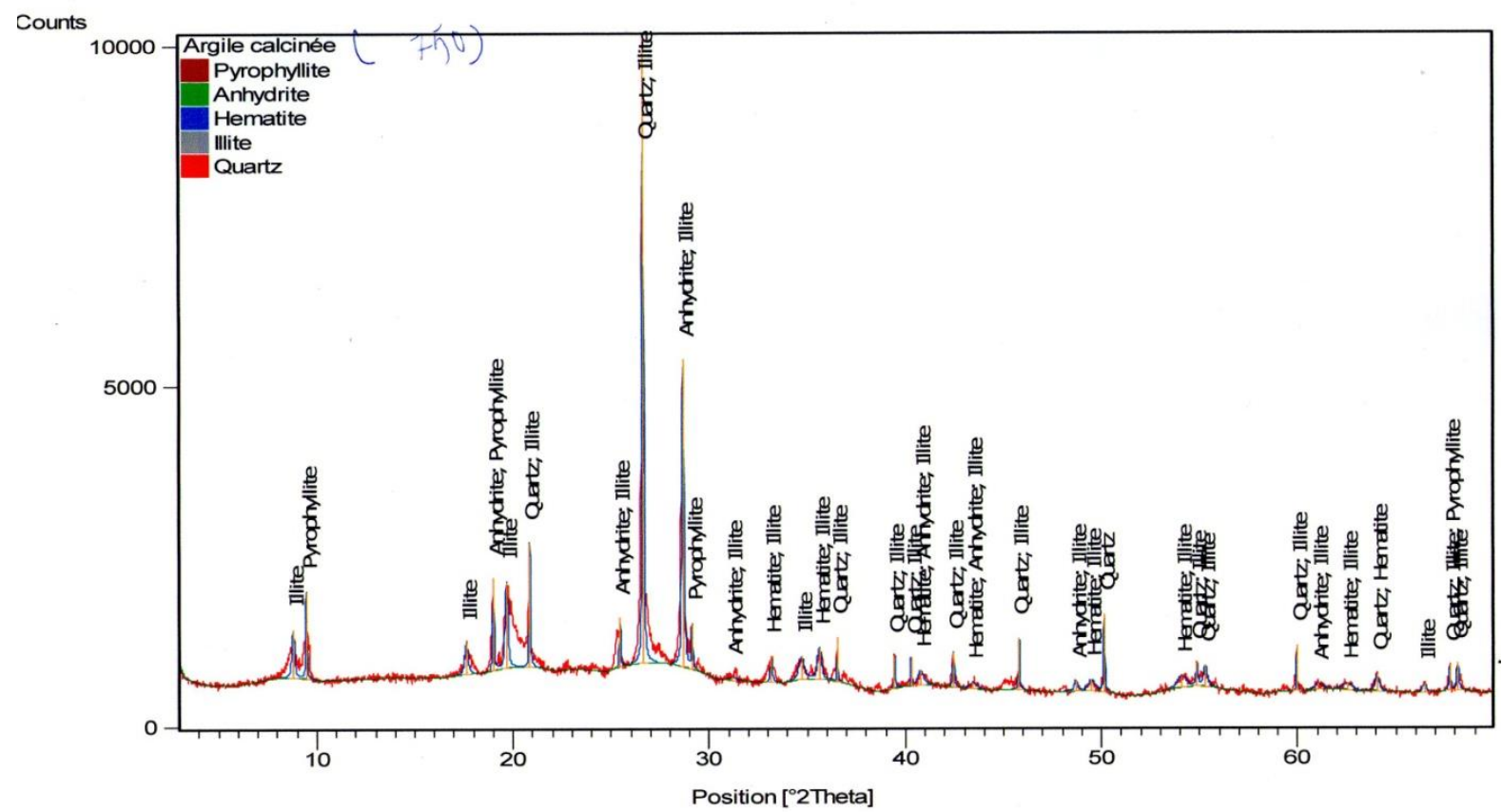

Fig 2. X-ray diffraction of the calcined pyrophyllite (Cu k $\alpha$ filter Ni)

\subsection{Formulation of self compacting concrete}

Based on the Japanese method (Okamura \& Ozawa, 1994), the self-compacting concrete was formulated. The basic data are optimized such as: Gravel to sand ratio G/S was fixed to 1 , the ratio of water to cement blended $\mathrm{W} / \mathrm{B}=0.38$ with the cement content $\mathrm{C}=450 \mathrm{~kg} / \mathrm{m}^{3}$, a rate of $10 \%$ and $20 \%$ of calcined pyrophyllite used as cement substitution was chosen and finally, a dosage of superplasticizer was kept constant at $1.7 \%$ by weight. Three compositions of SCC mixes were prepared, a control self-compacting concrete (SCC1) without CP and two concretes SCC2 and SCC3 containing $10 \%$ and $20 \%$ of CP. The mix proportion of self compacting concretes is presented in Table 3.

Table 3. Mix proportion of self-compacting concretes (kg.m-3)

\begin{tabular}{|l|l|l|l|}
\hline SCC/Constituent & SCC1 & SCC2 & SCC3 \\
& $0 \%$ CP & $10 \%$ CP & 20\% CP \\
\hline \hline Cement & 450 & 405 & 360 \\
\hline Limestone Fillers & 45 & 45 & 45 \\
\hline Calcined pyrophyllite CP & - & 45 & 90 \\
\hline Sand & 875 & 875 & 875 \\
\hline Coarse aggregate G3/8 & 346 & 346 & 346 \\
\hline Coarse aggregate G8/15 & 519 & 519 & 519 \\
\hline Water & 182 & 182 & 182 \\
\hline Superplasticizer & 8.42 & 8.42 & 8.42 \\
\hline
\end{tabular}




\subsection{Mixing, Casting, Curing and Testing Specimens}

For each SCC mixture, three prismatic samples $(70 \times 70 \times 280 \mathrm{~mm})$ and three cylindrical samples (110x220mm) were cast into steel molds according to standard NF EN 12390-2 (2012). The molds are kept in a room at ambient temperature, and after 24 hours demolded. To ensure proper curing of SCC concrete, the specimens were placed in a tank of water at a temperature of $20^{\circ} \mathrm{C} \pm 2^{\circ} \mathrm{C}$, this prevents water loss and to ensure normal operation of hydration process of cement. The concretes were then tested in compression according to NF EN 12390-3 (2012) standard, flexural according to NF EN 12390-5 (2012) and tensile according to NF EN 12390-6 (2012) at maturities $7 \mathrm{~d}, 14 \mathrm{~d}$ and 28 days.

Before casting, slump flow and $\mathrm{T}_{50}$ test of mobility of the fresh SCC (NF EN 12350-8, 2010), LBox test (NF EN 12350-10, 2010) and sieve stability test (NF EN 12350-11, 2010) were carried on each SCC mixture. Slump flow test is utilized to weigh flowability of SCC in lack of impediments. $\mathrm{T}_{50}$ test is used to weigh horizontal free flow in lack of impediments. A greater flowability is an indication of lower time. L-Box test measures filling and passing ability of SCC. Sieve stability test is performed to assess the stability of SCC.

\section{Results and Discussion}

\subsection{Influence of calcined pyrophyllite on fresh properties}

The results obtained on self-compacting concrete tested at fresh state (Flow test, L-Box, Sieve stability), show that all elaborated SCC with and without calcined pyrophyllite have good fresh properties (slump flow diameter, slump flow time $T_{50}$, passing ability and stability) that comply with the requirements prescribed by EFNARC (2005).

Figure 3-(a) illustrates the slump flow diameter of SCC. It is shown that for all SCCs, the slump flow was between $55 \mathrm{~cm}$ and $68 \mathrm{~cm}$, which is an indication of good deformability. When CP is incorporated in SCC, the slump flow results come under SF1 classes according to the EFNARC (2005) guidelines. The presence of calcined pyrophyllite decreased the slump flow diameter of self-compacting concrete. The reduction is 3\% for SCC2 and 11\% for SCC3. These results are confirmed by the values of the time $\mathrm{T}_{50}$. Figure 3-(b) shows that all SCC have slump flow times which are in the field of SCC (greater than $2 \mathrm{sec}$ ). $\mathrm{T}_{50}$ is classified into two classes in EFNARC (2005) guidelines i.e., VS1 and VS2, for VS1 class outcome is $\leq 2$ and for VS2 class outcome is $>2$. In this study, outcomes come under VS2 class.

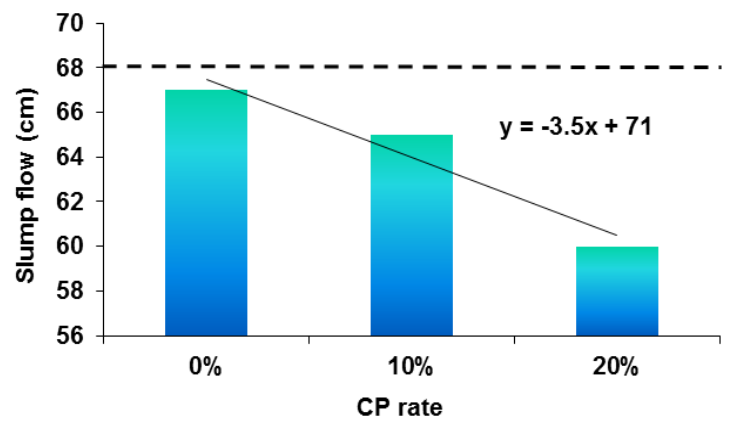

(a)

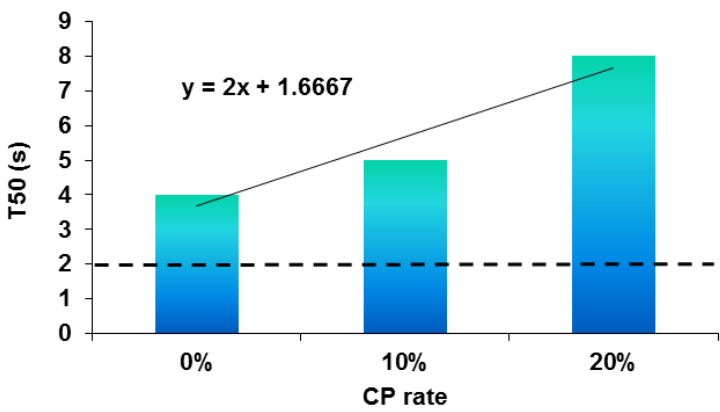

(b)

Fig 3. Influence of the rate of calcined pyrophyllite on (a)- Slump flow, (b)- Flow time $\mathbf{T}_{50}$ of SCCs.

Results showed that the time of flow to reach the $50 \mathrm{~cm}$ diameter increased with increase of CP rate. The presence of CP decreased the flowability and made the SCC more viscous compared to SCC1. Indeed, it was found during tests that when the CP rate increased, the concrete became less fluid and its placement in the test specimens was slow. The reduction in slump flow is probably due to the high fineness of $\mathrm{CP}$ compared to that of the cement, which can absorb the 
water and consequently decrease the flowability. Similar results have been reported in other researches when the calcined kaolin was used (Melo \& Carneiro, 2010; Hassan et al., 2010).

Moreover, the passing ability determined by L-Box is greater than 0.8 for all SCC. According to EFNARC guidelines (2005), L-Box test results $\geq 0.80$ comes under PA1 classes with 2 rebars and the test results $\geq 0.80$ comes under PA2 classes with 3 rebars. This is means that the risk of blockage is avoided. The passing ability decreased in the presence of $\mathrm{CP}$ when its rate increased from $10 \%$ to $20 \%$ (Figure 4 ). Compared to SCC1, the reduction of passing ability is $6 \%$ and $9 \%$ for SCC2 and SCC3 respectively.

Figure 5 illustrates effect of calcined pyrophyllite on the stability to segregation of SCCs. According to results, a decrease of segregation resistance of SCC was obtained with the increase of CP rate which translated into an increase of the percentage of milt. But, all the studied SCCs are stable (Milt $<15 \%$ ) and are classified as SR2. The SCC1 without CP is characterized by high stability (Milt $<5.14 \%$ ) and consequently a high resistance to segregation and to bleeding. SCC2 and SCC3 are homogeneous and less stable than SCC1. This is due to increase of the amount of CP fines in SCC witch facilitate the passage through the sieve and increases the milt weight.

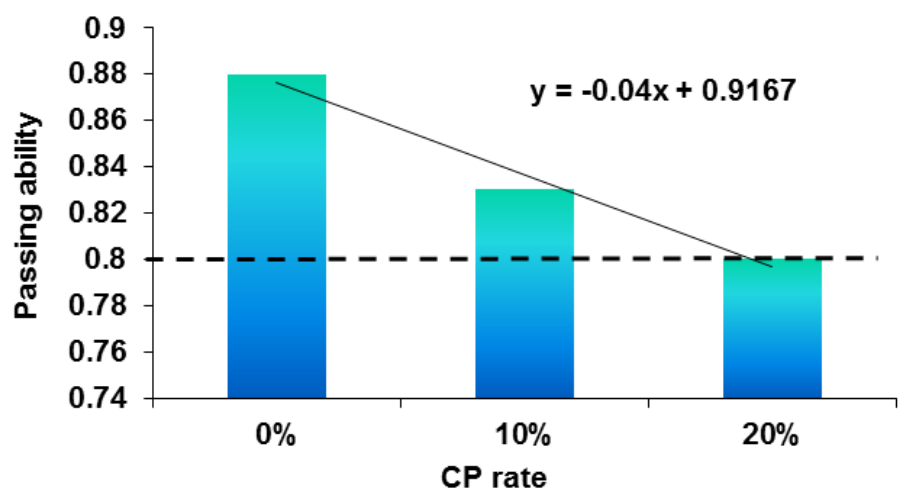

Fig 4. Influence of the rate of calcined pyrophyllite on the passing ability $\mathrm{H}_{2} / \mathrm{H}_{1}$ of SCCs.

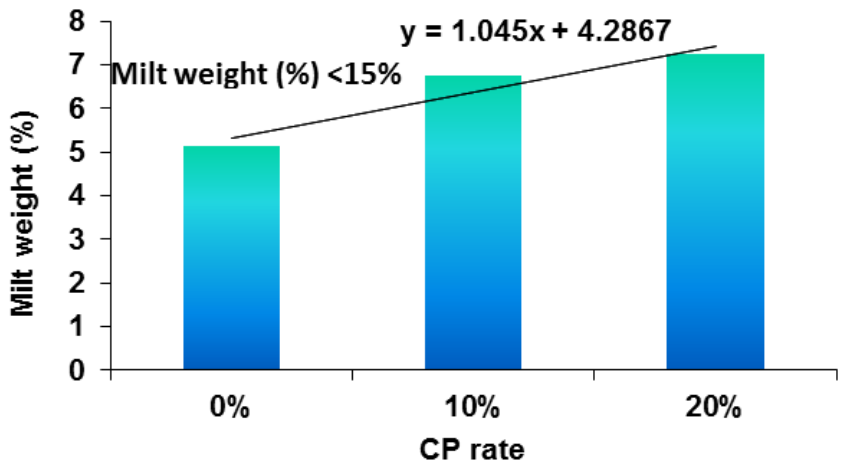

Fig 5. Influence of the rate of calcined pyrophyllite on the segregation rate/ Milt weight of SCCs.

In general, reduction in workability was attributed to few reasons such as greater fineness of addition than cement (Kim et al., 2012; Mo et al., 2018), and the rough morphology of particles could interlock and agglomerate together (Kim et al., 2012).

The three (03) SCC concretes all have a slump flow greater than $60 \mathrm{~cm}$, a quantity of milt less than $15 \%$ and a passing ability greater than $80 \%$, which confirms their self-compacting behavior. It seems that $10 \%$ is the optimum rate for good fresh properties of SCC. This concrete is classified as having a normal workability, plastic consistency and stability without risk of segregation. So, behavior of SCC2 at fresh state is similar to that of SCC1. 
Moreover, a correlation between Milt of sieve stability test and $\mathrm{T}_{50}$ was suggested. It is clear from the obtained results that the increase in $\mathrm{T}_{50}$ is associated to the increase of the milt and the decrease in resistance to segregation. The curve that describes this relationship is polynomial and the two properties are $100 \%$ related. The relation is expressed by the equation (1):

Milt weight $=-0.3658\left(\mathrm{~T}_{50}\right)^{2}+4.9125-8.6567$

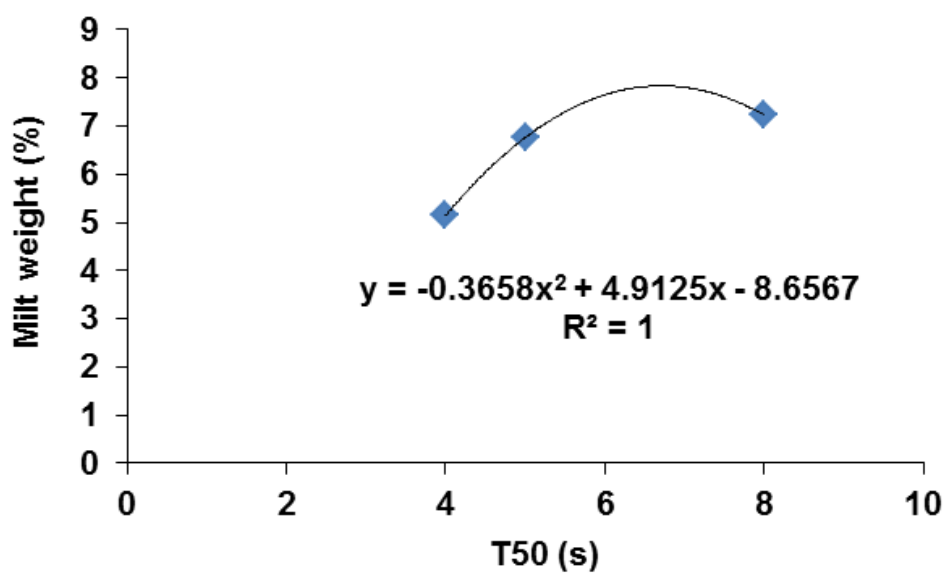

Fig 6. Relation-ship between flow $\mathrm{T}_{50}$ and Milt of sieve stability test.

\subsection{Influence of calcined pyrophyllite CP on hardened properties}

\subsubsection{Compressive strength}

Figure 6 shows that the increase of compressive strength as a function of the age is substantially similar for all samples tested SCC (Figure 6-(a)). Due to its high volume in Portland cement $\left(450 \mathrm{~kg} / \mathrm{m}^{3}\right)$, the control mix has for all ages the highest values of strength. Moreover, incorporation of calcined pyrophyllite as cement substitution decreases the compressive strength (Figure 6-(b)).

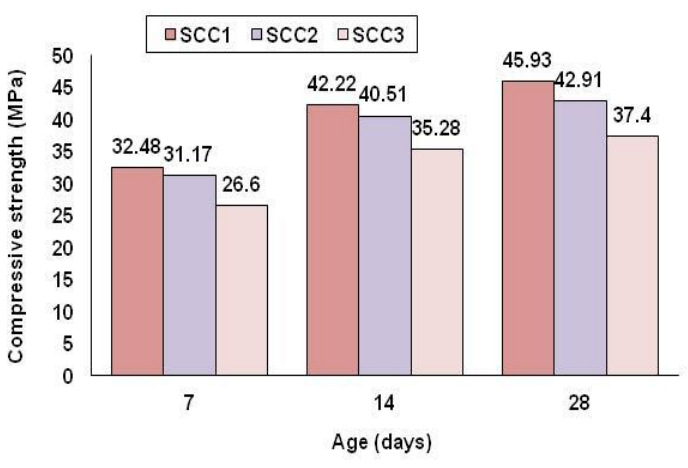

(a)

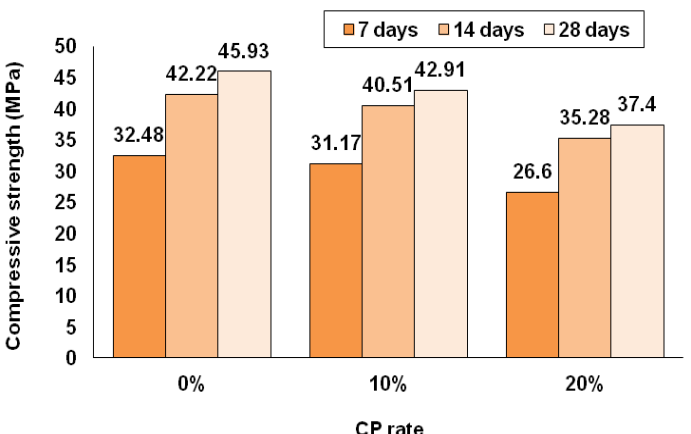

(b)

Fig 6. (a)-Compressive strength, (b)-Effect of $\mathrm{CP}$ rate on compressive strength.

The reduction is $4 \%$ and $18 \%$ at 7 days, $4 \%$ and $16 \%$ at 14 days, $7 \%$ and $19 \%$ at 28 days for SCC2 and SCC3 respectively. The rate of 10\% CP generates the lowest reduction at all ages. The strengths of SCC2 are almost comparable to those of SCC1. This decrease is due to the reduction of $\mathrm{C}_{3} \mathrm{~S}$ and $\mathrm{C}_{2} \mathrm{~S}$ minerals. These are the two main minerals that ensure the development of short and medium-term strength because they lead to the formation of CSH increasing the strength (Chinje and Billong, 2004; Baronio and Binda, 1997). Also, the water destined to cement wetting was mobilized by the CP due to its high fineness, which delayed the hydration process, therefore a decrease in strength has been recorded. Another reason is the low reaction rate of calcined 
pyrophyllite due to fact that cement type (CEM II) had a negative influence unlike rapid reaction rate of metakaolin and its ability to accelerate cement hydration. (Badogiannis et al., 2015; Akcay et al., 2016; Lenka and Panda, 2017; Barkat et al., 2019).

\subsubsection{Flexural strength}

Figure 7-(a) shows the increase of flexural strength as function of the age for the three compositions of SCC. The strengths of SCC2 and SCC3 at maturities of 7, 14 and 28 days do not reach those of SCC1. Substituted cement by calcined pyrophyllite $\mathrm{CP}$ reduced flexural strength at all maturities (Figure 7 -(b)). Reduction is $17 \%$ and $20 \%$ at 7 days, $17 \%$ and $31 \%$ at 14 days, $15 \%$ and $33 \%$ at 28 days for SCC2 and SCC3 respectively. The lowest reduction is obtained for concrete containing $10 \%$ of $\mathrm{CP}$.

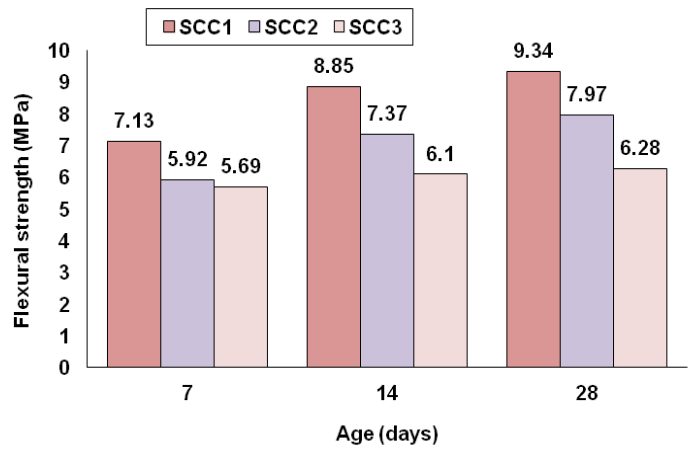

(a)

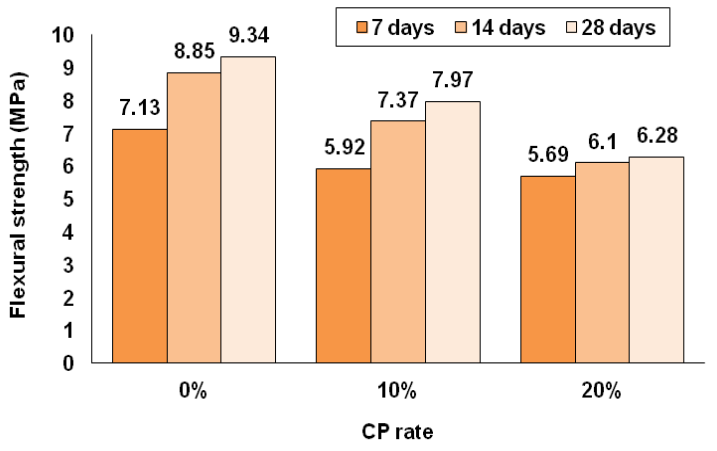

(b)

Fig 7. (a)-Flexural strengths, (b)-Effect of CP on flexural strength

\subsubsection{Tensile strength}

Figure 8-(a) clearly shows an increase in tensile strengths according to age for all SCC. Moreover, incorporation of calcined pyrophyllite decreased the tensile strength of SCC2 SCC3 at maturities 7, 14 and 28 days (Figure 8-(b)). Significant reduction was obtained. It is $25 \%$ and $33 \%$ at 7 days, $31 \%$ and $40 \%$ at 14 days, $22 \%$ and $39 \%$ at 28 days for SCC2 and SCC3 respectively. SCC2 mixture is the concrete witch developed tensile strengths approaching those of the control.

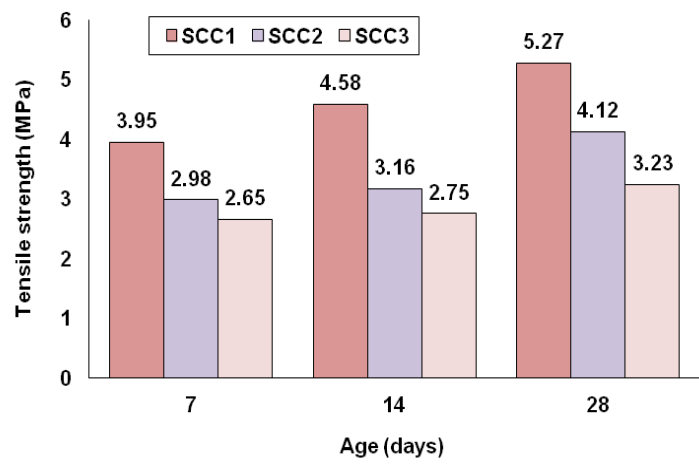

(a)

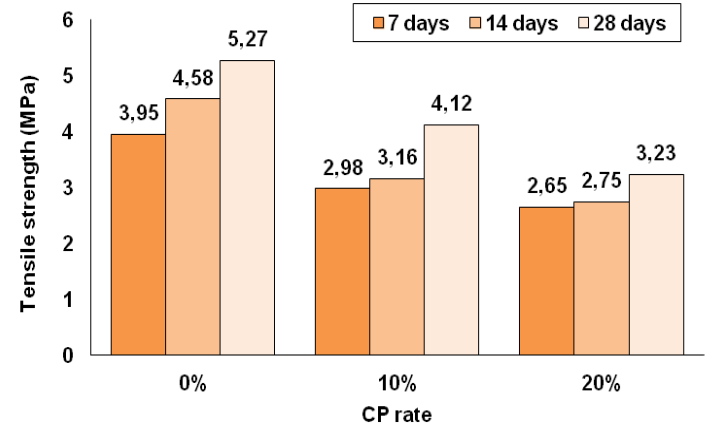

(b)

Fig 8. (a)-Tensile strength, (b) Effect of $\mathrm{CP}$ on tensile strength.

\section{Conclusions}

This investigation was conducted to assess the fresh and hardened properties of reduced environmental impact SCC made with calcined pyrophyllite. From the obtained results following conclusions can be drawn: 
- The slump flow of SCCs is between $55 \mathrm{~cm}$ and $68 \mathrm{~cm}$, which is an indication of good deformability. It decreases in presence of calcined pyrophyllite. The lowest reduction of $3 \%$ was obtained for SCC containing $10 \% \mathrm{CP}$.

- In the other hand, the flow time $\mathrm{T}_{50}$ increased with the increase of the rate of calcined pyrophyllite from $10 \%$ to $20 \%$ and a slowdown in the flow of SCC was observed.

- The passing ability is greater than 0.8 for all SCC. This is means that the risk of blockage is avoided According to EFNARC guidelines (2005). The passing ability decreased in the presence of calcined pyrophyllite when its rate increased from $10 \%$ to $20 \%$. The $6 \%$ lowest reduction is obtained for SCC incorporating $10 \%$.

- The segregation resistance decreased increase of CP rate. But, all the studied SCCs are stable (Milt < 15\%) and are classified as SR2. SCC2 and SCC3 are homogeneous and less stable than SCC1

- It seems that $10 \%$ is the optimum rate for good workability properties of SCC2 compared to $20 \%$. This concrete is classified as having a normal workability, plastic consistency and satisfactory stability is to say no risk of segregation.

- Behaviour of SCC2 contained 10\% of calcined pyrophyllite at fresh state is similar to that of control SCC1 concrete.

- An excellent relationship between Milt of sieve stability test and flow time $\mathrm{T}_{50}$ was suggested. The two properties are correlated at $100 \%$.

- The use of calcined pyrophyllite as $10 \%$ and $20 \%$ cement substitution in concrete SCC slows down the hardening process of concrete, consequently producing lower strengths of SCC concretes.

- At 28 days, for self-compacting concrete containing 10\% CP, reduction is $7 \%$, for compressive strength, $15 \%$ for flexural strength and $22 \%$ for tensile strength.

- The rate of $10 \% \mathrm{CP}$ seems to generate mechanical strengths approaching those of the SCC control.

Workability and mechanical tests show results that support the use of cement with calcined pyrophyllite as part of an economical and environmental self-compacting concrete.

\section{References}

ACI (2003). Processes, Self-Compacting Concrete", Advanced Concrete Technology III, 3, 203 - 209.

Aghabaglou, M. A., Sezer, G. İ., \& Ramyar, K. (2014). Comparison of fly ash, silica fume and metakaolin from mechanical properties and durability performance of mortar mixtures view point. Construction and Building Materials, 70, 17-25.

Akcay, B., Sengul, C., \& ali Tasdemir, M. (2016). Fracture behavior and pore structure of concrete with metakaolin. Advances in Concrete Construction, 4(2), 71-88.

Amritphale, S. S., Bhasin, S., \& Chandra, N. (2006). Energy efficient process for making pyrophyllite-based ceramic tiles using phosphoric acid and mineralizers. Ceramics international, 32(2), 181-187.

Anggraini, R., Ristinah, R., Budio, S. P., Soewignyo, S. R., \& Firmaninda, W. (2014). The Effect Of Pyrophyllite Use As Admixture In Light Concrete Bricks's Mechanical Properties. Rekayasa Sipil, $7(3), 210-217$.

Badogiannis, E. G., Sfikas, I. P., Voukia, D. V., Trezos, K. G., \& Tsivilis, S. G. (2015). Durability of metakaolin self-compacting concrete. Construction and Building Materials, 82, 133-141. 
Barkat, A., Kenai, S., Menadi, B., Kadri, E., \& Soualhi, H. (2019). Effects of local metakaolin addition on rheological and mechanical performance of self-compacting limestone cement concrete. Journal of Adhesion Science and Technology, 33(9), 963-985.

Belaidi, A. S. E., Kenai, S., Kadri, E. H., Soualhi, H., \& Benchaâ, B. (2016). Effects of experimental ternary cements on fresh and hardened properties of self-compacting concretes. Journal of adhesion science and Technology, 30(3), 247-261.

Belaidi, A. S. E., Azzouz, L., Kadri, E., \& Kenai, S. (2012). Effect of natural pozzolana and marble powder on the properties of self-compacting concrete. Construction and Building Materials, 31, 251-257.

Bijeljié, J., Paunovie, S., Nesovië, I., \& Milosevié, B. (2014). Inflence of calcined clays on the fresh properties of self-compacting concrete. International conference contemporary achievements in civil engineering, Subotica, SERBIA. 509-515.

Boukhelkhal, A., Azzouz, L., Belaïdi, A. S. E., \& Benabed, B. (2016). Effects of marble powder as a partial replacement of cement on some engineering properties of self-compacting concrete. Journal of adhesion science and Technology, 30(22), 2405-2419.

Boukhelkhal, A. (2012). Rheology, physical and mechanical characterization and durability of selfcompacting concrete made with marble powder. [MSc thesis]. University Amar Telidji of Laghouat, Algeria. p.170.

Busari, A., Dahunsi, B., Akinmusuru, J., Loto, T., \& Ajayi, S. (2019). Response Surface Analysis of the Compressive Strength of Self-Compacting Concrete Incorporating Metakaolin. Advances in Science and Technology Research Journal. 13(2): 7-13.

Baronio, G., \& Binda, L. (1997). Study of the pozzolanicity of some bricks and clays. Construction and Building Materials, 11(1), 70-78.

Chinje, M., \& Billong, N. (2004). Activité pouzzolanique des déchets de briques et tuiles cuites. African Journal of Science and Technology (AJST), Science and Engineering Series, 5(1): 92-100.

Demez, A., \& Karakoç, M. B. (2020). Mechanical properties of high strength concrete made with pyrophyllite aggregates exposed to high temperature. Structural Concrete, 1-10. https://doi.org/10.1002/suco.201900381.

Dembovska, L., Bajare, D., Pundiene, I., \& Vitola, L. (2017). Effect of pozzolanic additives on the strength development of high performance concrete. Procedia Engineering, 172, 202-210.

EFNARC (2005). European guidelines for self-compacting concrete: specification, production and use. Selfcompacting concrete European project group.

Hassan, A. A. A., Lachemi, M., \& Hossain, K. M. A. (2010). Effect of metakaolin on the rheology of selfconsolidating concrete. In Design, production and placement of self-consolidating concrete (pp. 103-112). Springer, Dordrecht.

Kim, H. K., Hwang, E. A., \& Lee, H. K. (2012). Impacts of metakaolin on lightweight concrete by type of fine aggregate. Construction and Building Materials, 36, 719-726.

Krajči, L., Kuliffayová, M., \& Janotka, I. (2013). Ternary cement composites with metakaolin sand and calcined clayey diatomite. Procedia Engineering, 65, 7-13.

Lauw, C.G.S., \& Besari, M.S. (2001). Performance of calcined pyrophyllite in lightweight expanded clay concrete. 26th Conference on Our World in Concrete \& Structures, Singapore. 385-392.

Lenka, S., \& Panda, K. C. (2017). Effect of metakaolin on the properties of conventional and self compacting concrete. Advances in concrete construction, 5(1), 01-48.

Madandoust, R., \& Mousavi, S. Y. (2012). Fresh and hardened properties of self-compacting concrete containing metakaolin. Construction and Building Materials, 35, 752-760.

Mansour, M. S., Abadlia, M. T., Jauberthie, R., \& Messaoudene, I. (2012). Metakaolin as a pozzolan for highperformance mortar. Cement Wapno Beton, 17(2), 102-108.

Mansour, M.S., Abadlia, M.T., Afalfiz, A., \& Ladaoui, W. (2013). Rhéologie du mortier et du béton contenant des ajouts minéraux. Journal of Cement WAPNO Beton. 5, 264-270. 
Melo, K. A., \& Carneiro, A. M. (2010). Effect of Metakaolin's finesses and content in self-consolidating concrete. Construction and Building Materials, 24(8), 1529-1535.

Mo, K. H., Mohd Anor, F. A., Alengaram, U. J., Jumaat, M. Z., \& Rao, K. J. (2018). Properties of metakaolinblended oil palm shell lightweight concrete. European Journal of Environmental and Civil Engineering, 22(7), 852-868.

Mukhopadhyay, T. K., Ghatak, S., \& Maiti, H. S. (2009). Effect of pyrophyllite incorporation in porcelain composition on mechanical properties and microstructure. Ceramics International, 35(7), 25552562.

Mukhopadhyay, T. K., Ghatak, S., \& Maiti, H. S. (2010). Pyrophyllite as raw material for ceramic applications in the perspective of its pyro-chemical properties. Ceramics International, 36(3), 909-916.

NF EN 12350-8 (2010). Essai pour béton frais - partie 8: béton autoplaçant - Essai d'étalement au cône d'Abrams.

NF EN 12350-10 (2010). Essai pour béton frais - partie 10: béton autoplaçant - Essai à la boite en L.

NF EN 12350-11 (2010). Essai pour béton frais - partie 11: béton autoplaçant - Essai de stabilité au tamis.

NF EN 12390-2 (2012). Essais pour béton durci - Partie 2: confection et conservation des éprouvettes pour essais de résistance.

NF EN 12390-3 (2012). Essais pour béton durci - Partie 3: résistance à la compression des éprouvettes.

NF EN 12390-5 (2012). Essais pour béton durci - Partie 5: résistance à la flexion sur éprouvettes.

NF EN 12390-6 (2012). Essais pour béton durci - Partie 6 : détermination de la résistance en traction par fendage.

Okamura, H., \& Ozawa, K. (1994). Self compactable high performance concrete. International Workshop on High Performance Concrete, American Concrete Institute, Detroit. 31-44.

Ouldkhaoua Y, Benabed B, Abousnina R, Kadri H, (2020). Experimental study on the reuse of cathode ray tubes funnel glass as fine aggregate for developing an ecological self-compacting mortar incorporating metakaolin. Journal of Building Engineering. 27, 100951.

Ouldkhaoua, Y., Benabed, B., Abousnina, R., Kadri, E. H., \& Khatib, J. (2020). Effect of using metakaolin as supplementary cementitious material and recycled CRT funnel glass as fine aggregate on the durability of green self-compacting concrete. Construction and Building Materials, 235, 117802.

Rabehi, B., Ghernouti, Y., \& Driss, M. (2014). Potential use of calcined silt of dam as a pozzolan in blended Portland cement. International Journal of Concrete Structures and Materials, 8(3), 259-268.

Rashad, A. M. (2015). Metakaolin: Fresh properties and optimum content for mechanical strength in traditional cementitious materials-A comprehensive overview. Reviews on Advanced Materials Science, 40(1), 15-44.

Samet, B., Mnif, T., \& Chaabouni, M. (2007). Use of a kaolinitic clay as a pozzolanic material for cements: Formulation of blended cement. Cement and Concrete Composites, 29(10), 741-749.

Terzić, A., Radulović, D., Pezo, M., Stojanović, J., Pezo, L., Radojević, Z., \& Andrić, L. (2020). Prediction model based on artificial neural network for pyrophyllite mechano-chemical activation as an integral step in production of cement binders. Construction and Building Materials, 258, 119721.

Tregger, A.N., Pakula, M. E., Shah, S. P. (2010). Influence of clays on the rheology of cement pastes, Cement and Concrete Research, 40: 384-391.

Uysal, M., \& Sumer, M. (2011). Performance of self-compacting concrete containing different mineral admixtures. Construction and Building materials, 25(11), 4112-4120. 